\title{
Outlandish Christendom: The Catholic Church in India and China
}

\section{Abstract}

The Catholic Church, like Christianity more generally, has a marginal presence in India and China yet continues to face severe challenges. At least in part this is due to the fact that, in either case, Christianity is outlandish from a civilizational perspective. Despite these similarities, the challenges express themselves in different ways. In China, they mostly emanate from the state and express themselves as government restrictions. In India, they mostly emanate from society and express themselves as social hostilities. This difference is due to the fact that, in either case, Christianity is outlandish in a different way. In China, Christianity is foreign to a Han-centric imperial tradition: the state used to dominate religion and harness it for its purposes whenever the opportunity arose. In India, Christianity is foreign to a previously subaltern society: despite non-Hindu rule, Hindu elites have always been able to reproduce their hegemony. In both cases, the perceived foreignness of Christianity is reinforced by unpleasant memories of missionary activities during the colonial and imperialist period. When it comes to Catholicism, this is aggravated by the fact that the Church looks to an identifiable head (the Pope) and headquarters (the Vatican) located in distant Europe. Despite these challenges, there are also opportunities for Catholicism, and Christianity more in general. The final section discusses ways to navigate the challenges and pursue the opportunities.

\section{Acknowledgments}

An earlier version of this article was presented at the conference Popes on the Rise! Mobilization,

Media, and the Political Power of the Modern Papacy, organized by Mariano Barbato and held on the Campo Santo Teutonico adjacent to the Vatican City in Rome. Subsequent research assistance from Raphael Bradenbrink and comments from an anonymous reviewer are gratefully acknowledged. 


\section{Introduction}

India and China have much in common. Both look back to ancient civilizational legacies, have in recent years (re)gained respect as pivotal powers and leading economies in rising Asia, and have enormous populations. As far as the Church is concerned, either has a small percentage of Christians and an even smaller percentage of Catholics. But there are also important differences. China is an autocratic state with an officially atheist society that has mixed feelings towards religion, whereas India is a vibrant democracy with a Hindu-majority population that is deeply suspicious of religions seen as foreign, sometimes to the point of communal violence against religious minorities. India and China always make for an interesting comparison, but they also make for interesting contrast.

Religious freedom is a case in point. China and India both pose severe constraints on religion, but they do so in different ways. China has strong government restrictions but moderate social hostilities. India has high social hostilities but moderate government restrictions. The Pew Research Centre defines government restrictions as the ways that national and local governments restrict religion, including through coercion and force. Social hostilities relate to violence and intimidation in societies, which can also limit religious beliefs and practices. ${ }^{1}$ The figure below presents restrictions on religious freedom in the world's 25 most populous countries. The contrast between China and India is stark. Indeed, no other pair of countries shows a more striking contrast (Figure 1).

\footnotetext{
${ }^{1}$ Peter Grim, "Restrictions on religion in the world," in The Future of Religious Freedom, ed. Allen D. Hertzke (New York: Oxford University Press, 2013), 86-104.
} 


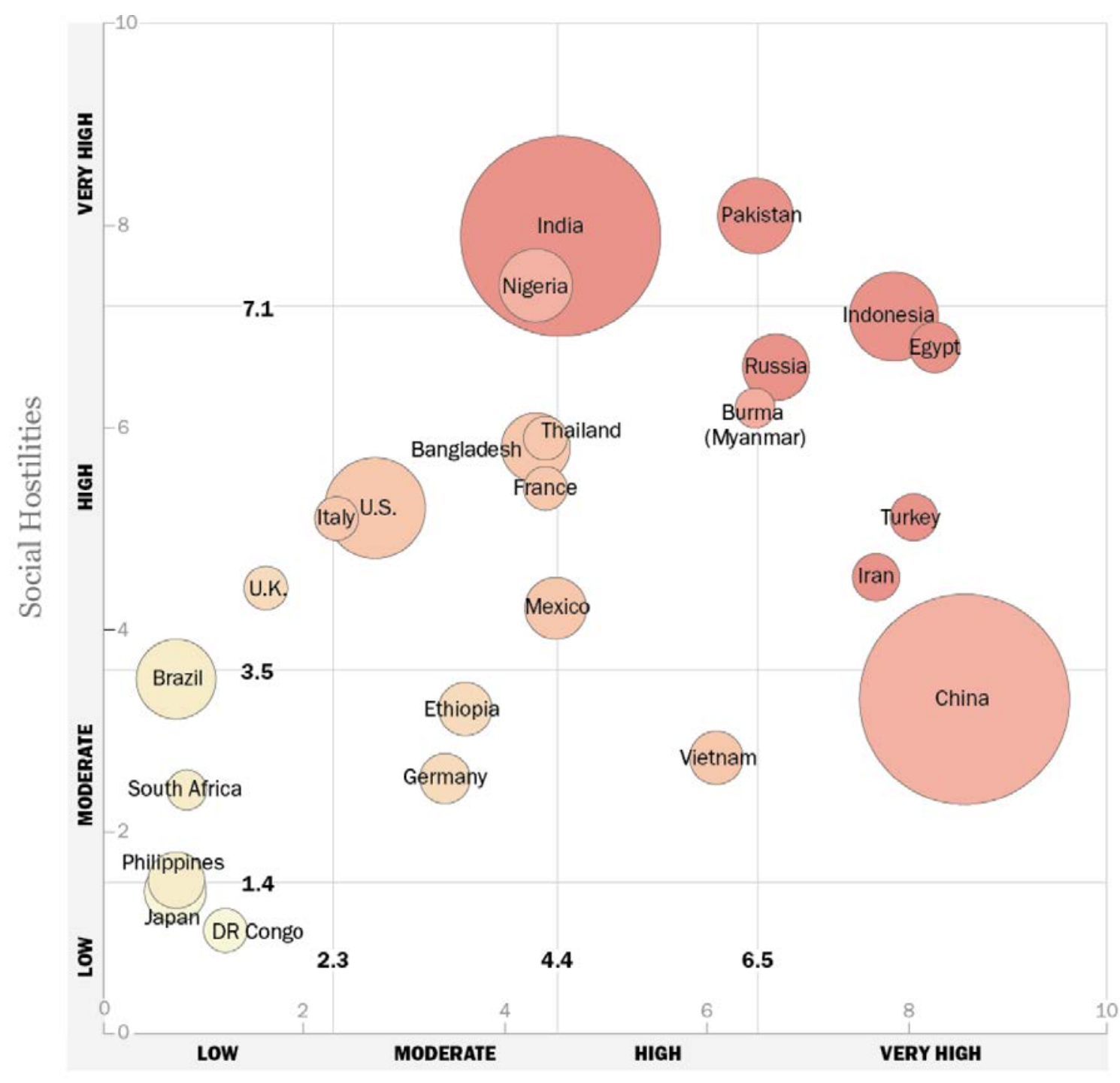

Government Restrictions

Figure 1: Restrictions on religion in the 25 most populous countries. Source: Pew Research Center, Trends in Global Restrictions on Religion (Washington, DC: Pew Research Center, 2016), 28.

In either case, the restrictions on religion are related to the fact that Christianity appears foreign to the country's civilizational legacy. From the perspective of Chinese or Indian civilization, Christianity appears like an outlandish monotheistic cult. Interestingly, the same applies to Islam. While in the West and in the Middle East monotheism is seen as normal and the cleavage between Christianity and Islam seems enormous, a reversed-telescope view from China and India compels us to see how similar both are bound to appear from the perspective of non-Abrahamic world civilizations. 
In the specific case of Catholicism, the perceived foreignness of Christianity is aggravated by the fact that the Church looks to an identifiable head (the Pope) and headquarters (the Vatican) located in distant Europe. Missionary activities are associated with unpleasant memories from the colonial and imperialist period. This is despite the fact that, in the early modern era, Catholic missionaries pursued strategies of cultural adaptation to reduce the real or perceived foreignness of their religion. In China, Matteo Ricci (1552-1610) dressed like a Confucian sage and tried to reconcile Christianity with ancestor worship. In India, Roberto de Nobili (1577-1656) donned the garb of a Hindu renouncer and appealed to the caste consciousness of Brahmins. However, cultural adaptation entered a crisis in either country with the so-called rites controversies of the 18th century and was abandoned during the colonial and imperialist period. It has more recently been revitalized after the Second Vatican Council (1962-1965), in the wake of seminal documents promoting "inculturation," such as Gaudium et Spes, Lumen Gentium, and Ad Gentes. ${ }^{2}$

In this article I show how Christendom is outlandish to China and India alike. The Church faces constraints on religious freedom in either country, but in ways that are different due to distinct civilizational legacies: an imperial legacy of socio-spatial hierarchy in China, and a sociocultural legacy of Hindu hegemony in India. I introduce these legacies in the next section. This is followed by a discussion of challenges for the Church in either country. My focus is on the Catholicism, although most findings are more widely applicable to other Christian denominations. Despite the challenges, there are also opportunities for Catholicism, and Christianity more in general. In the conclusion, I suggest ways for the Church to navigate the challenges and pursue the opportunities.

\footnotetext{
2 Patricia G. Panganiban, "Inculturation and the Second Vatican Council," Landas 18, no. 1 (2004): 59-93. On inculturation in India, see Paul M. Collins, Context, Culture and Worship: The Quest for "Indian-ness" (New Delhi: ISPCK, 2006). On inculturation in China, see Peter R. Moody, "The Catholic Church in China today: the limitations of autonomy and enculturation," Journal of Church and State 55, no. 3 (2013): 403-431.
} 


\section{Civilizational legacies}

Previous research on Sino-Muslim and Hindu-Muslim relations suggests that, even today, ancient civilizational legacies structure the ways majorities in China and India relate to religious and ethnic minorities. ${ }^{3}$ In China, Han-Muslim relations rest on an informal socio-spatial hierarchy according to which the pivotal Han view some groups, such as the Sinicized Hui Muslims, as more of an asset, and others, such as the Turkic Uyghur Muslims, as more of a liability. In India, Muslims have been inserted into a hegemonic structure that has allowed Hindu elites to determine sociocultural order despite centuries of non-Hindu rule. For most of Indian history, a core of upper castes has presided over a fragmented society of progressively lower (or lesser) castes, as well as outcastes.

These legacies are equally relevant for Sino-Christian and Hindu-Christian relations. In China, the Sinocentric socio-spatial hierarchy left by the imperial tradition of rule is now enforced by the (post-) communist state. Given the character of that state, Beijing does not accept any alternate source of authority, frustrating the desire of Chinese Catholics to communicate with Rome. In India, the hegemonic structure of Hinduism comes with an idealized self-perception of inclusiveness that has paradoxical effects on encounters with others. Hindus are inclusive towards those willing to accept their allocated place, but they can be rather intolerant against those who refuse to do so.

\section{Chinese hierarchy}

While promoting modern western ideologies like communism or capitalism, the Chinese state also looks back to an ancient Han- or Sinocentric tradition of ruling minorities. Even the vernacular name

\footnotetext{
${ }^{3}$ Jörg Friedrichs, "Sino-Muslim relations: the Han, the Hui, and the Uyghurs," Journal of Muslim Minority Affairs 37, no. 1 (2017): 55-79. Jörg Friedrichs, Indian Perspectives on Hindu-Muslim Relations, book manuscript.
} 
of China, zhongguo or zhonghua, contains the notion of "central" or "middle" (zhong, 中). Despite fluctuation in use, the self-understanding of China as the "Middle Kingdom" is very ancient. ${ }^{4}$

Since time immemorial, a basic modality of Chinese rule has been the ethnocentric allocation of status and privilege to different groups depending on their degree of acculturation. This has led to an informal socio-spatial hierarchy, with some groups seen as closer to the center than others. For example, Hui Muslims are Sinicized, seen as religiously moderate, and most of them live next to Han Chinese neighbors. Muslims of Central Asian extraction, such as the Turkic Uyghurs, live further from the Chinese heartland and are seen as culturally alien and prone to religious extremism. ${ }^{5}$

Classical Chinese cosmography represented the world as five "concentric geographical zones emanating outward from the capital: royal domains, princely domains, a pacification zone, the zone of allied barbarians, and the zone of savagery." ${ }^{6}$ This imperial worldview dates from the sixth century BC and goes back to the Book of Documents, one of the classics of ancient Chinese literature. ${ }^{7}$ The tributary system of later dynasties, such as the Ming and early Qing (ca. 1368-1841), was a similar attempt to maintain a "social hierarchy defined in cultural and civilizational terms", with the Middle Kingdom located at the center and surrounded by "inner" and "outer" barbarians. ${ }^{8}$

In this system, religion has always played a role in establishing the level of cultural affinity or distance, with western monotheistic religions perceived as more distant than East and South Asian forms of religiosity, which in turn were seen as somewhat distant from indigenous Chinese traditions like Taoism and, ultimately, the high-cultured Confucianism embraced by the imperial court. With the demise of the Empire, this took a more sociocultural tinge but the fundamental structure

\footnotetext{
${ }^{4}$ Luke S.K. Kwong, "What's in a name: zhongguo (or 'Middle Kingdom') reconsidered," Historical Journal 58, no. 3 (2015): 781-804.

${ }^{5}$ Friedrichs, "Sino-Muslim relations: the Han, the Hui, and the Uyghurs."

${ }^{6}$ Richard J. Smith, Chinese Maps: Images of "All Under Heaven" (Hong Kong: Oxford University Press, 1996), 2324.

${ }^{7}$ See James Legge, The Chinese Classics, vol. 3 (Hongkong and London: Trübner \& Co., 1865), 142-149.

${ }^{8}$ Yongjin Zhang and Barry Buzan, "The tributary system as international society in theory and practice," Chinese Journal of International Politics 5, no. 1 (2012): 3-36, 14-15. For a classical study, see J.K. Fairbank and S.Y. Têng, "On The Ch'ing Tributary System," Harvard Journal of Asiatic Studies 6, no. 2 (1941): 135-246.
} 
remains in place. Even today, scholars working in China find concentric and multi-layered "ethnogeographies" of cultural affinity and distance, with the urban Han Chinese at the apex or core. ${ }^{9}$

It is easy to see why Christians in general, and Catholics in particular, are on the outer fringes of this Han-centric hierarchy. Not only do they follow a western Abrahamic religion, like the Muslims, but they are also in communion with foreign spiritual heads, like the Pope, and organizational headquarters, like the Vatican. From the vantage point of the contemporary Chinese state, the presence of Christians is disturbing for two additional reasons: the Communist Party is officially atheist, and it does not tolerate any centers of allegiance other than itself. At the same time, the state is trying to harness religion to promote a "harmonious society." Even this can be traced back to an ancient imperial tradition. Whenever the Empire had the capacity to control and harness religion, it would do so. Typically, "it was the state that shaped the contours of religious politics." ${ }^{10}$

\section{Indian hegemony}

Whereas the Chinese state harks back to the imperial legacy of a centralized civilization, Indian society stands in continuity with a civilization that, for much of its history, was subaltern and fragmented yet at the same time based on Hindu hegemony. The bedrock of the "power dynamic underlying Indian civilization" is that an elitist "Hindu core" invariably dominates society. ${ }^{11}$

What has persisted through history is a rather continuous civilizational structure that is recognizably Indian and which takes the form of an extended dialogue between an overlapping network of groups who consider themselves, and are considered by others to be

\footnotetext{
${ }^{9}$ Stevan Harrell, ed. Cultural Encounters on China's Ethnic Frontiers (Seattle: University of Washington Press, 1995); Susan D. Blum, Portraits of "Primitives": Ordering Human Kinds in the Chinese Nation (Lanham: Rowman \& Littlefield, 2001); Susan K. McCarthy, Communist Multiculturalism: Ethnic Revival in Southwest China (Seattle: University of Washington Press, 2009).

${ }^{10}$ II Hyun Cho and Peter J. Katzenstein, "In the service of state and nation: religion in East Asia," in Religion and International Relations, ed. Jack Snyder (New York: Columbia University Press, 2011), 168-199, 170.

${ }^{11}$ Cynthia Keppley Mahmood, "Rethinking Indian communalism: culture and counter-culture," Asian Survey 33, no. 7 (1993): 722-737, 723.
} 
at the center of society, and other groups-sometimes overlapping, sometimes discrete-who consider themselves, and are considered by others, to be at the periphery of the society. ${ }^{12}$

For most of the past 2,500 years, Indians were under Buddhist, Muslim, Sikh, or Christian rulers, yet preserved this sociocultural or socio-religious structure. They did so by reproducing a hegemonic order whereby a social core (Aryans first, Brahmins and Kshatriyas later, then upper castes, today forward castes) presides over multiple layers of subaltern groups. In a way, this hegemonic order is what Hinduism is all about. The most marginal subjects fall outside the formal social structure, and are treated as outcastes. Despite their abject status, Hinduism needs outcastes to accept Hindu hegemony rather than joining some other sociocultural system.

In today's democratic society, a formal and explicit ideology sanctioning the rule of elites over the rest of society is not acceptable. Therefore, the upper castes have reinvented themselves as forward castes. The lower castes have been rechristened "other backward classes" (OBCs). The outcastes are now called "scheduled castes and scheduled tribes" (SC/STs). Despite this euphemistic guise, the hegemonic structure remains. An upper crust of Hindu elites continues to preside over layers and layers of supposedly lesser people. Backward castes are accommodated through "reservations" and affirmative action, and pursue upward social mobility through Sanskritization. ${ }^{13}$

Officially, Indian society now includes those formerly considered untouchable, as well as Christians and other religious minorities-if, that is, they are willing to accept Hindu hegemony. Those unwilling to do so remain outsiders at the fringes of society, sometimes accommodated in patronizing ways, sometimes repudiated, and sometimes relegated to the margins. This makes it easy to understand why Christianity, especially when adopted by Dalits or "Tribals," is seen as a threat to Hindu hegemony, leading to what the Pew Research Center calls social hostilities.

\footnotetext{
12 Ibid., 730.

${ }^{13}$ M.N. Srinivas, "A note on sanskritization and westernization," Far Eastern Quarterly 15, no. 4 (1956): 481-496.
} 


\section{The Church in India}

Hinduism is the last polytheist world civilization standing. The Roman Empire became Christian in antiquity. Subsequently, pagans in Northern and Eastern Europe were baptized. Soon after the Prophet died, Persia became Muslim. The Americas became Christian in the early modern era. Animists in Africa and elsewhere were converted to Christianity or Islam. China, Japan, and Korea have jettisoned their shamanist traditions. Buddhism is the dominant religion in Sri Lanka, Thailand, Myanmar, and Bhutan. Pakistan, Bangladesh, and Afghanistan are Muslim-majority countries. Only India, as well as nearby Nepal, continue to be dominated by polytheist majorities.

This is no minor feat. Hinduism (15\%) is the third largest world religion in terms of its share of the global population, trailing Christianity (31\%) and Islam (23\%). ${ }^{14}$ Only $14.2 \%$ of Indians are Muslim, despite the fact that Muslims have ruled most of India for at least six centuries. Only $2.3 \%$ are Christian, although Europeans have ruled India for another couple of centuries. Less than $1 \%$ of Indians are Buddhist and less than $2 \%$ are Sikh, although Buddhism and Sikhism have also been associated with powerful dynasties. ${ }^{15}$ According to Jawaharlal Nehru, India's first Prime Minister, all of these (mostly foreign) challengers "came, made a difference, and were absorbed." 16

To be sure, given India's enormous population, $2.3 \%$ Christians means 27.8 million people. In terms of religious demography, there are concentrations of Christians in the South (Kerala and Tamil Nadu) and Northeast (especially the "tribal" states surrounding Assam). Estimates vary, but it is safe to assume that at least 10 million of India's Christians are Roman Catholic. Formerly Portuguese Goa remains an important Catholic hub. However, the so-called Latin Church is not the oldest Church in India. It came to India in early modern times, whereas the so-called Thomas Christians have been

\footnotetext{
${ }^{14}$ Pew Research Center, The Future of World Religions: Population Growth Projections, 2010-2050 (Washington, DC: Pew Research Centre, 2015), 6.

${ }^{15}$ The figures are from the 2011 population census.

${ }^{16}$ Jawaharlal Nehru, The Discovery of India (London: Meridian, 1946), 50.
} 
present in the South ever since the first, or possibly second or third, century. The Thomas Christians are Eastern Catholics following Syrian liturgical rites and number at least 3 million people. ${ }^{17}$

\section{Tolerant Hinduism?}

There is a preconceived notion that Hinduism is uniquely tolerant of spiritual diversity and respectful of other religions. How could a religion with thousands of deities and hundreds of sects and schools not be tolerant? The meme about Hindu tolerance and respect is almost ubiquitous among Hindus and non-Hindu observers alike. It has also been embraced by secularist Indians, including Nehru who saw Hindu syncretism as the civilizational bedrock of a modern democratic India. ${ }^{18}$

While being enthralled by the idea of tolerant Hinduism, Hindu nationalists show the limitations and ironies of this idea. A leader of the Vishva Hindu Parishad (VHP), a right-wing organization based on the ideology of Hindutva (Hindu-ness), puts it like this: "I am Jain, no doubt. I worship my Jain tradition, my Jain gods. But I have respect for Jesus, I have respect for Mohammad, I have respect for Sai Baba, because I am Hindu." The flipside is that others must respect Hinduism: "Faith should be respected, as we respect the faith of other people. You say: 'Our Mary is Virgin. Jesus took birth from Virgin Mary.' All right, I do not have any right to say that your faith is wrong." ${ }^{19}$

So far, so tolerant. As an RSS officer puts it: "In our RSS, there is a clear message to all: If you criticize Christianity, if you criticize Islam, if you criticize any fundamentalism, take care! Those who are great men in that religion, you may follow them or not, but you should not talk disrespectfully. Even in our shakha [gathering], we never abuse Isa [Jesus], we never abuse Mohammad. We always respect them." ${ }^{20}$ An intellectual associated with the Hindu nationalist Rashtriya Swayamsevak Sangh (RSS) claims that, unlike western secularism, Indian secularism is "respect for all religions." In his

\footnotetext{
${ }^{17}$ Paul Pallath, The Catholic Church in India (Rome: Mar Thoma Yogam, 2003).

${ }^{18}$ Nehru, The Discovery of India.

${ }^{19}$ Surendra Jain, All-India Secretary of the Vishva Hindu Parishad (VHP), Rohtak, 7 August 2015.

${ }^{20}$ Indresh Kumar, RSS leader and "guide" of the Muslim Rashtriya Manch, New Delhi, 11 August 2015.
} 
view, the only thing a good Indian must do is identify as a child of Bharat Mata (Mother India) before anything else. "If this is realized by all religious people, there will be no religious conflict."21

All of these citations have one feature in common. Respect is not only something one must have for others but also something one may require from them in return. Accordingly, professed tolerance and respect have a paradoxical, less tolerant and respectful, flip side: If you don't respect our religion, take care. You are free to believe what you want, but your key loyalty must be to Mother India. If this is so, what to do with those who refuse to fully identify as children of Mother India, for example because they see themselves primarily as children of God, or children of Abraham?

Especially but not exclusively in Hindu nationalist circles, there is deep-seated resentment against the real or perceived Christian lack of respect. An official from the governing Bharatiya Janata Party (BJP) suspects that Christian missionaries, in an attitude of contempt against Hinduism as an inferior belief system, operate on the motto: "Let us convert these snake healers to true religion." 22 According to the VHP leader cited above, the act of proselytization implies that missionaries consider their own religion as superior to that of others, which is "the most heinous crime against humanity." He indignantly refers to a book entitled Harvesting the Souls, published by Christian missionaries. "Are our souls the crops which they are going to harvest?" His tirade culminates in the following accusation: "They are abusing our goddess Kali. They are abusing our Krishna. They are abusing our Rama. They are abusing our entire culture. They are abusing our entire religious dogmas."23

Hindus see themselves as uniquely tolerant, inclusive, and respectful. However, this is conditional on others reciprocating the courtesy and renouncing exclusivist claims and disrespectful attitudes. At a deeper level, Hindu tolerance and inclusiveness are conditional on the acceptance of a Hindu-centric worldview whereby other belief systems can only ever be varieties of the spiritual truth supremely expressed by Hinduism. Thus, tolerant Hinduism may easily turn into its mirror image. This is not to

\footnotetext{
${ }^{21}$ Justice Rama Jois, Hindu intellectual (RSS), Bangalore, 17 July 2015.

22 High-ranking BJP party official (anonymous), New Delhi, 7 August 2015.

${ }^{23}$ Surendra Jain, All-India Secretary of the Vishva Hindu Parishad (VHP), Rohtak, 7 August 2015.
} 
deny that Hindus are uniquely tolerant towards those who howsoever remotely accept their standards of recognition, but precisely this makes them less tolerant towards those who follow their own standards of recognition and do not sufficiently abide by norms of Hindu hegemony. ${ }^{24}$

\section{Outcaste Christianity}

For all its professed tolerance and inclusiveness, Hinduism has hegemonic pretentions that are bound to clash with Christianity as a monotheist, universalistic, and soteriological religion. While Christians might avoid this by playing down the theological and doctrinal aspects of their faith, Christianity is also predestined to clash with Hindu hegemony when it comes to proselytization. Since time immemorial, social order in India has been based on the supremacy of the upper castes. The most marginal subjects would be treated as outcastes. Whichever way such outcastes are classified, for example as Dalits or Tribals, the preservation of Hindu dharma (order) requires outcastes to acquiesce with their subordination to the hegemony of Hindu elites. ${ }^{25}$

Therefore, outcaste conversion is deeply resented in upper-caste and middle-class Hindu circles.

Dalit and Tribal converts are sometimes harassed by their Hindu neighbors, and the Indian state has made sure they lose access to state support such as job reservations. Christian charities offering resources to marginal groups, especially when receiving foreign support, face the accusation of coveting the conversion of needy but unwitting people by means of allurement or fraud. ${ }^{26}$

There was this earthquake in Nepal. Why did Christian missionaries go there with Bible? Did they need Bible, or some sort of food or shelter? They were insulting their remedies, they

\footnotetext{
24 Paul Hacker, "Inklusivismus," in Inklusivismus: Eine Indische Denkform, ed. Gerhard Oberhammer (Wien: Institut für Indologie der Universität Wien, 1983), 11-28; see also the discussion in Wilhelm Halbfass, India and Europe: An Essay in Understanding (New York: SUNY Press, 1988), 403-418.

${ }^{25}$ Louis Dumont, Homo Hierarchicus: The Caste System and its Implications, Revised ed. (Chicago: University of Chicago Press, 1980); Murray Milner, Status and Sacredness: A General Theory of Status Relations and an Analysis of Indian Culture (New York: Oxford University Press, 1994).

${ }^{26}$ Chad M. Bauman, "Hindu-Christian conflict in India: globalization, conversion, and the coterminal castes and tribes," Journal of Asian Studies 72, no. 3 (2013): 633-653.
} 
were insulting their tragedies. The Nepal government had to say, please get out, we don't need Bible at this time. We need food, we need some type of help for these people. ${ }^{27}$

This is largely rhetorical. In fact, Hindu outrage at outcaste conversion is related not so much to any real or perceived insult or disrespect but rather to the fear that outcastes might elude Hindu hegemony by joining another religion such as Christianity, Buddhism, or Islam. Those invested in the preservation of Hindu hegemony have reason to fear that, if outcaste conversions were to happen at mass level, this might pose a serious threat to the preservation of sociocultural order.

Historically, the caste system has been resilient and brittle at the same time. On the one hand, Hindus are proud that their civilization has withstood centuries of Christian rule and missionary activity. According to a senior Congress politician, in the early modern period the Jesuits were "stunned" by Hindu recalcitrance. "Whereas they had an easy time converting African coastal tribes to Christianity, when they arrived in India they were faced with an immovable object. They tried hard to give the message of the Lord, but it was not being accepted." ${ }^{28}$ On the other hand, elite Hindus are well aware that outcastes are getting a raw deal. They have reason to fear that their allegiance to Hinduism is tenuous, and that especially Dalits and Tribals may want to defect from Hinduism and convert to another religion such as Christianity, Buddhism, or Islam.

To some extent this has already happened. Most of India's Muslims are the progeny of outcaste and lower-caste converts. Scores of Dalits followed their leader B.R. Ambedkar into Buddhism. Likewise, the followers of the Roman Catholic Church are predominantly from Dalit and Tribal communities. A policy document of the Catholic Bishops' Conference of India (CBCl) states: "Dalits are about 12 million out of 19 million members of the Catholic Church." The figures are debatable, but it is fair to

\footnotetext{
${ }^{27}$ Surendra Jain, All-India Secretary of the Vishva Hindu Parishad (VHP), Rohtak, 7 August 2015.

${ }^{28}$ Mani Shankar Aiyar, MP Rajya Sabha (Congress), New Delhi, 10 August 2015.
} 
say that most of India's Roman Catholics-unlike the Thomas Christians in the South-are Dalits. Worryingly for the Hindu establishment, the $\mathrm{CBCl}$ is committed to Dalit empowerment. ${ }^{29}$

This goes back to the 19th Century, when the Catholic Church made inroads into subsections of Indian society that were underprivileged and therefore somewhat alienated from the Hindu establishment. Missionaries made many converts among untouchables (later called Harijans; now called Dalits), as well as tribal people living on the margins of Hindu society. For all of these people, conversion held the promise of social emancipation and better access to resources.

All the planes of Manipur are vaishnavite [i.e. people there worship Vishnu]. Most of the tribal hill areas are Christian. There is also some smattering of Buddhism. They became Christians because the Hindu maharaja was not willing to accept them into the Hindu fold. He held that the Vedic literature cannot be read by anyone other than Brahmins and Kshatriyas. ${ }^{30}$

The result is a tension between Hindu pride and insecurity. Take for example the words of the VHP leader cited above. On the one hand, he is proud that Hinduism has been so resilient to conversion ("It is due to the strong bonds in our religion." "It is our nature, we love our religion very much."). On the other hand, he appears to be concerned that Christian missionaries might actually succeed. Not only is he furious at the claim of Christian missionaries that Tribals are animists rather than Hindus. He also claims that Christian missionaries are notorious for trying "to divide Indian society into different sections" and for supporting various antinational forces, including tribal insurgents and foreign NGOs. Like other Hindu nationalists, he takes pride in the tolerant and inclusive nature of Hinduism. But when it comes to outcaste conversion, his stance is the opposite: "No. It is not like we have our treasures in the open: Anyone can come and pick them up. Loot is there, and everyone is coming and looting. Christian missionaries, Mohammedan people. Hinduism is not so weak." 31

\footnotetext{
${ }^{29} \mathrm{CBCl}$, Policy of Dalit Empowerment in the Catholic Church in India (New Delhi: Catholic Bishops' Conference of India, 2016), 9.

${ }^{30}$ Satish Sahney, Head of the Nehru Centre, Mumbai, 31 July 2015.

${ }^{31}$ Surendra Jain, All-India Secretary of the Vishva Hindu Parishad (VHP), Rohtak, 7 August 2015.
} 
Upper-caste Christianity

When the Roman Catholic Church entered India in early modern times, conversion efforts were initially concentrated on Brahmins. According to a Congress politician, Catholic missionaries found it impossible to convert any upper-caste Hindus into Christianity without allowing them to retain their caste. "The European missionaries found themselves caught in the horns of a dilemma between harvesting souls for Christ and being faced with a very strong social system. They compromised by allowing the social system to continue." ${ }^{32}$ Thus, what is now praised as inculturation, was actually based on the acceptance of upper-caste supremacy over the rest of Hindu society.

Today, Christians from upper-caste or middle-class backgrounds are seen as less disturbing than those from Dalit or Tribal backgrounds. The Thomas Christians, for example, have always been mostly upper-caste-and they are hardly seen as a threat. ${ }^{33}$ Almost nobody in India takes issue with privileged Christians, and some point to the Roman Catholic Sonia Gandhi as a flagship figure. Only Dalit and tribal Christians, but not others, are the target of reconversion efforts. ${ }^{34}$ By the same token, while Christians providing services to marginalized groups are mostly unwelcome, Christian services for the privileged are rather welcome. As a Jesuit educator points out, Christians are only $2.3 \%$ of India's population, but "if you look at the 10 top colleges every year in India, at least $50 \%$ of them are Christian." ${ }^{35} \mathrm{~A}$ secularist politician is proudly calls himself a "Jesuit product" and proclaims with satisfaction that India's upper-caste Christians "have done very well professionally." ${ }^{36}$

Kerala is another case in point. Nowhere in India, except for formerly Portuguese Goa, is Christianity as firmly entrenched. One reason is sheer numbers. Kerala has 55\% Hindus, $27 \%$ Muslims, and $18 \%$ Christians (2011 census). Another reason is political dynamics. Neither the Left Democratic Front

\footnotetext{
${ }^{32}$ Mani Shankar Aiyar, MP Rajya Sabha (Congress), New Delhi, 10 August 2015.

${ }^{33}$ C.J. Fuller, "Kerala Christians and the Caste System," Man 11, no. 1 (1976): 53-70.

${ }^{34}$ Manjari Katju, "The politics of Ghar Wapsi," Economic \& Political Weekly 50, no. 1 (2015): 21-24.

${ }^{35}$ Father Ambrose Pinto, Principal of St Aloysius College, Bangalore, 19 July 2015.

${ }^{36}$ High-level Congress politician (anonymous), New Delhi, 4 August 2015.
} 
(LDF) nor the Congress has been able to win any election in Kerala without Christian and Muslim support. This led to the alternation of governments led by either the Congress or the LDF. Either way, Christians and Muslims have been rewarded with representation in government and access to state resources. A third reason is the higher-caste and hence rather "developed" character of the minorities in Kerala and Tamil Nadu. A fourth reason is Christian education which, again, is rather welcome. An academic from Kerala points out that Christian missionaries are famous for affordable elite education. "They have spread their educational institutes all over the state [of Kerala]. That has given an opportunity for people to get education without having to spend too much money." ${ }^{37}$

\section{The Church in China}

The number of Christians in China is difficult to estimate. The Pew Research Center estimates them at 67 million, or $5 \%$ of the population. Within that, about 9 million (0.7\%) are Catholic, including 5.7 million people affiliated with the state-approved Chinese Patriotic Catholic Association (CPCA) and conservatively estimated-3.3 million people affiliated with the so-called underground Church. ${ }^{38}$ Others estimate the number of Chinese Protestants at 20-40 and Catholics at 6-10.5 million. ${ }^{39}$

Like in India, Catholics in China are a small diaspora and Catholicism is seen as a foreign religion. Unlike in India, however, challenges arise from government restrictions rather than social hostilities. It is therefore appropriate to focus on relations between religion and state authorities, both in a contemporary and in a historical perspective. ${ }^{40}$ As will become clear, the picture looks rather different depending on whether one takes a short and narrow, or a long and broad view.

\footnotetext{
${ }^{37}$ P.K. Shajahan, Dean at the Tata Institute of Social Sciences, Mumbai, 30 July 2015.

38 Pew Research Center, Global Christianity: A Report on the Size and Distribution of the World's Christian Population (Washington, DC: Pew Research Forum, 2011), 97-98.

${ }^{39}$ Katharina Wenzel-Teuber, private communication, 14 March 2017; Katharina Wenzel-Teuber, "Statistics on religions and churches in the People's Republic of China: update for the year 2016," Religions and Christianity in Today's China 7, no. 2 (2017): 26-53.

${ }^{40}$ For an ethnographic account of the religious revival in Chinese society, see lan Johnson, The Souls of China: The Return of Religion After Mao (London: Allen Lane, 2017).
} 


\section{A short and narrow view}

A short and narrow view suggests that Christianity, and especially Catholicism, faces problems in China due to the hostility of the Communist Party and state authorities. This is the picture one gets when looking at Christianity in isolation from other religions and when one contemplates only the history since the anti-colonial mobilization starting in the mid-nineteenth century. Some historians take an even narrower view, starting in the early twentieth century, after the end of the Civil War (1949) or after the onset of Deng Xiaoping's reform era (1978). In this view, the history before $1949 / 1978$ is largely a precursor for present Chinese communist hostility to the Church ${ }^{41}$ Such short and narrow views are not wrong, but stunted. They miss crucial points, as the next section shows.

According to the standard account, Chinese patriots saw Christians with suspicion after the Christian-inspired Taiping rebellion (1850-1864). Due to their association with western imperialism, Christians were later targeted by the anticolonial Boxer rebellion (1899-1901). Despite widespread resentment against the foreign character of Christianity, the missionary establishment did not surrender control. Acting under French patronage, it took the Catholic Church until 1926 to consecrate native Chinese bishops. By the mid-1920s, missionaries were denounced as agents of foreign imperialism and, with the outbreak of Civil War in 1927, became targets of mass nationalism. Most missionaries were forced to leave China during the upheaval of the next 25-30 years. ${ }^{42}$

After the end of the Civil War in 1949, Catholics in particular were "a nightmare for the Party to get under control" because they remained loyal to the Pope. Even so, by the late 1950s, the Party was able to cobble together enough support for the Chinese Patriotic Catholic Association to run the

\footnotetext{
${ }^{41}$ Cindy Yik-yi Chu, ed. Catholicism in China, 1900-Present: The Development of the Chinese Church (New York: Palgrave Macmillan, 2014); Cindy Yik-yi Chu, The Catholic Church in China: 1978 to the Present (Palgrave: Macmillan, 2013).

${ }^{42}$ Daniel H. Bays, "China," in The Wiley Blackwell Companion to World Christianity, ed. Lamin O. Sanneh (Hoboken, NJ: Wiley Blackwell, 2016), 393-402; Daniel H. Bays, A New History of Christianity in China (Malden, MA: Wiley Blackwell, 2012).
} 
Church independently from Rome and "self-select" and "self-ordain" its bishops. The victorious Communists were "the first in over a century to be able to implement the measures of control that the Qing and Republican-era governments undoubtedly would have liked to have extended." ${ }^{43}$

In defiance of communist control, Vatican loyalists formed an underground hierarchy and network to bypass the CPCA. After the deep freeze of the Cultural Revolution (1966-1976), when all religion was suppressed, the official and underground Church both reemerged at the onset of the reform era (1978). Relations between the official and underground Church remain complicated, with most believers belonging to both entities but clergy sometimes forced to choose either side.

Underlying this, there is a conflict of loyalty, or what Beatrice Leung calls "conflicting authority," between China and the Vatican. ${ }^{44}$ Rome, on the one hand, demands sole authority over doctrinal and ecclesiastical affairs. Beijing, on the other hand, claims that the ultimate loyalty of Chinese Catholics belongs to the nation and that allegiance to foreign organizations is "unpatriotic". Hence, the need for the Chinese Patriotic Communist Association. In theory, the CPCA is autonomous, selfgoverning, and independent from Rome. In practice, however, it is of course directed by the Chinese state and Communist Party, and therefore utterly dependent on Beijing's fiat.

By the same token, there is disagreement about the purpose of the church. While most believers and clerics worldwide would agree that the Church is a community of believers, Beijing is interested in the church as a sociocultural organization. Alongside other non-Communist associations, Beijing wants to harness churches for "United Front work" to promote social stability and build a powerful state. But, at the same time, Beijing is unwilling to accept any alternate centers of authority that might challenge the supremacy of the Communist Party over all aspects of life and society. This reinforces the urge to subordinate churches to the control of state authorities and, ultimately, the

\footnotetext{
${ }^{43}$ Bays, "China," 399; Bays, A New History of Christianity in China, 169-174.

${ }^{44}$ Beatrice Leung, Sino-Vatican Relations: Problems in Conflicting Authority, 1976-1986 (Cambridge: Cambridge University Press, 1992).
} 
Communist Party. In the specific case of the Catholicism, Papal authority over the Church is unacceptable to Beijing precisely because it is such an essential feature of Catholicism. ${ }^{45}$

At the level of church governance, conflicts arise most acutely when it comes to the appointment of church leaders. Especially regarding the ordination of bishops, Beijing and Rome radically contest one another's authority. For Rome, bishops are to the Pope like the apostles to Peter. Like Peter was the shepherd of the apostles, the Pope is the guardian of the bishops. For Beijing, papal approval of bishops might be desirable as it augments the authority of state-appointed church leaders, but papal sovereignty over the consecration of bishops amounts to unacceptable foreign interference. ${ }^{46}$

While this sounds neat in theory, the actual situation is rather messy. Since the 1980s and 1990s, a tacit custom has evolved whereby new bishops are normally selected from a set of priests approved by both the Vatican and the Chinese regime. Even when an "illicit" (or "non-approved") ordination takes place, Rome hardly ever openly excommunicates anyone. ${ }^{47}$ Many illicit bishops subsequently seek to be "reconciled" or "received into communion" with The Vatican. Yet, there is room for ambiguity because, according to canon law, illicit bishops excommunicate themselves automatically (latae sententiae). Even those reconciled with Rome usually do not disclose their reconciliation, to avoid problems with the Chinese authorities. The ambiguity places all parties involved, including church officials and common believers, into an awkward and difficult situation. ${ }^{48}$

Although not officially confirmed, it seems that, on a practical level, agreement on the ordination of bishops has recently been reached. ${ }^{49}$ This would be a major breakthrough, removing one of the

\footnotetext{
45 Moody, "The Catholic Church in China today: the limitations of autonomy and enculturation," 430.

46 Yi Yang, "Between God and Caesar: the Catholic bishops' election and consecration in China," Journal of Contemporary China, no. forthcoming (2017).

${ }^{47}$ Moody, "The Catholic Church in China today: the limitations of autonomy and enculturation," 406, 425.

48 Paul P. Mariani, "The four Catholic bishops of Shanghai: "underground" and "patriotic" church competition and Sino-Vatican relations in reform-era China," Journal of Church and State 58, no. 1 (2016): 38-56.

${ }^{49}$ Victor Gaetan, "The Vatican and China reach a promising accord," Foreign Affairs March 27(2017).
} 
thorniest issues more than three decades after John Paul II launched a first attempt to normalize relations between the Vatican and Beijing, and between the official and underground church. ${ }^{50}$

Interestingly, Benedict XVI failed to reach such a breakthrough. In 2007, Benedict wrote a pastoral letter to the Church in China that was also seen as an indirect signal that the Vatican was interested in a rapprochement with Beijing. ${ }^{51}$ However, it seems that Chinese authorities did not appreciate the oblique way Benedict sent his message and resented by the very act of addressing the faithful rather than approaching state authorities through discreet communication channels. While there seemed to be a certain thaw in the first few years after the letter, 2010-2013 saw a renewal of hostilities. The official Church ostentatiously appointed various "illicit" bishops, and Rome took the extraordinary step of explicitly excommunicating such bishops in three cases. ${ }^{52}$

Then a new guard entered the scene. Xi Jinping became President on 14 March 2013, the day after Francis had been elected Pope. The ascension of the new leaders provided an opportunity for resetting China-Vatican relations. Unlike his predecessor, Francis chose the path of quiet diplomacy and, starting in June 2014, held several rounds of semisecret backchannel talks. ${ }^{53}$ The talks took almost three years to come to fruition. Even at the time of writing, in August 2017, the deal has not been officially confirmed by either side. Over the entire duration of the process, hardline critics such as Cardinal Joseph Zen, former Bishop of Hong Kong, lambasted the very attempt of negotiating a deal with Beijing as a "betrayal of Christ" as well as the underground church. ${ }^{54}$

\footnotetext{
${ }^{50}$ Leung, Sino-Vatican Relations: Problems in Conflicting Authority, 1976-1986.

51 Jean-Paul Wiest, "Sino-Vatican relations under Pope Benedict XVI: from promising beginnings to overt confrontation," in Catholicism in China, 1900-Present: The Development of the Chinese Church, ed. Cindy Yik-Yi Chu (New York: Palgrave Macmillan, 2014), 189-216.

52 Rachel Xiaohong Zhu, "The division of the Roman Catholic Church in Mainland China: History and Challenges," Religions 8, no. 3 (2017): 14 pp., 3; Moody, "The Catholic Church in China today: the limitations of autonomy and enculturation," 425-426; see also Beatrice Leung and Marcus J.J. Wang, "Sino-Vatican negotiations: problems in sovereign right and national security," Journal of Contemporary China 25, no. 99 (2016): 467-482. ${ }^{53}$ Victor Gaetan, "The Pope and the Politburo: the Vatican's Chinese diplomacy," Foreign Affairs March 24(2016). ${ }^{54}$ Benjamin Haas and Tom Phillips, "Pope's possible deal with China would 'betray Christ', says Hong Kong cardinal," The Guardian, 28 November 2016; CNN, "As atheist China warms to the Vatican, religious persecution 'intensifies'," CNN, 28 February 2017.
} 
Critics like Cardinal Zen may have a point. A pragmatic deal on the ordination of bishops does not solve the fundamental conflict over loyalty and the disagreement over the purpose of the church, leaving Chinese Catholics vulnerable. As long as both sides remain pragmatic, however, progress seems possible. For example, Rome has for a long time wanted to establish normal diplomatic relations with Beijing. At present, the Vatican still recognizes Taiwan, which is unacceptable to Beijing. However, this may change rather quickly. Already in 2005, the Holy See's Secretary of State Cardinal Sodano declared: "If we could have ties with Beijing, then-not tomorrow but tonight-the nuncio or rather the chargé d'affaires in Taiwan, would head for Beijing." 55

\section{A long and broad view}

The short and narrow view is helpful when it comes to making sense of current affairs. However, the history of Christianity in China is much older than the short and narrow view suggests. Also, Chinese Christians does not exist in isolation but as part of a wider religious landscape. As we will see, a bigpicture view is necessary to capture long-term trends that may be important for the future.

To begin with, it is important to acknowledge that Christianity has been in and out of China for almost 1,400 years. ${ }^{56}$ Except for a short interlude (ca. 1840-1925), Christians have always relied on what is now called inculturation. It is also important to note that, not only in China but also elsewhere in East Asia, religion has never had much standing of its own. Whenever the state had the capacity to control religion, it would do so. "East Asia's historical experience suggests that religion was typically not confined to the private domain but always a matter central to the state." 57

The first wave of Christianity in China started in 635, at the beginning of the Tang dynasty (618-907), when the Nestorian Church of the East entered the Middle Kingdom from the west. The Nestorians

\footnotetext{
55 Cited in Wiest, "Sino-Vatican relations under Pope Benedict XVI: from promising beginnings to overt confrontation," 193.

${ }^{56}$ For an authoritative overview, see Bays, A New History of Christianity in China; see also Bays, "China."

${ }^{57}$ Cho and Katzenstein, "In the service of state and nation: religion in East Asia," 171.
} 
made themselves acceptable by constructing their teachings as compatible with the indigenous Chinese tradition of Daoism, as well as Buddhism which was widely accepted at the time. In the midninth century, however, all foreign religions including Buddhism fell from imperial grace under Emperor Wuzong. This also hit Christianity, which had initially been cautiously patronized.

Some tribal allies of Genghis Khan, such as the Keraites, were Nestorian Christians. In 1245, Pope Innocent IV sent Giovanni da Pian del Carpine to the court of the Great Khan, to see if an alliance against the advance of Islam might be possible. Soon after, when Kublai Khan, a grandson of Genghis Khan, had conquered China, Christianity saw a revival. A few years after Marco Polo had visited the Mongol court, Pope Nicholas IV sent Giovanni da Montecorvino, who reached China in 1294. After the collapse of the Mongol Yuan dynasty (1271-1368), however, Christianity and other western religions suffered a blow under the notoriously xenophobic rule of the early Ming dynasty.

Another chapter for Christianity in China began with the arrival of the Jesuits under Francis Xavier in 1552. Francis Xavier died a premature death, but his successor Matteo Ricci continued his mission. When Ricci came to China in the late 16th century, Christianity had all but disappeared, although there may still have been a smattering of "secret Christians," or at least a spiritual substratum, in areas where the Church of the East had previously been endemic. ${ }^{58}$ The strategy followed by the Jesuits was to make Catholicism acceptable to Chinese patrons by constructing Christian teachings as compatible with Confucianism, including practices of ancestor worship. Initially, the Jesuits were rewarded by the favor of the Imperial court and could evangelize rather freely.

In the early 18th century, however, the toleration of ancestor worship came under fire in the European homelands of the missionaries. The Chinese Emperor was not amused and decreed that missionaries were welcome in China only if they set their quarrels aside and followed the "rites of Ricci." When Pope Clement XI confirmed his opposition to these rites, the Emperor decreed a ban on

\footnotetext{
${ }^{58}$ Diarmaid MacCulloch, A History of Christianity: The First Three Thousand Years (London: Penguin, 2010), 267-
} 272. 
Catholicism. The Church was subsequently persecuted under the Yong Zheng and Qianlong emperors (1724-1796). Catholic communities survived in rural areas, but the Church was in a crisis.

The situation changed only with the "opening" of China after the Opium War (1840). Western missionaries acted in unison with the imperialist powers, and Catholics were joined by Protestant missionaries. Missionary activities became inseparable from cultural imperialism. This made Christian missionaries, and by association Christianity tout court, unwelcome at a time of millenarian upheaval (Taiping rebellion) and proto-nationalist ferment (Boxer uprising). This is the period from which the short and narrow view usually starts, neglecting the historical longue durée.

In addition to taking a longer view, taking a broader view is another eye-opening move. Christianity is only one of several religious traditions in China. This is important because, as discussed in the section on civilizational legacies, minorities in China are treated in terms of their cultural proximity to, or distance from, the civilizational core, or apex, of an informal socio-spatial hierarchy. In the contemporary version of this socio-spatial hierarchy, the urban Han are the civilizational benchmark against which the level of acculturation of various minorities is measured and compared.

The socio-spatial hierarchy is applied not only to ethnic groups but also to religious minorities. Confucianism is celebrated as an indigenous school of spiritual wisdom. Taoism is also welcomed as an indigenous religious tradition. Confucianism and Taoism both receive generous state support, although localized Taoist practices are somewhat frowned upon as superstitious folk religion. Despite its foreign origin, non-Tibetan Buddhism is highly Sinicized and receives a favorable treatment. Islam is seen as more foreign but has been endemic for many centuries. More Sinicized followers of Islam, such as the Hui Muslims, are monitored with a watchful eye but mostly left unscathed. The same cannot be said about the Uyghurs, which are of Central Asian stock and seen as hardly Sinicized. Christianity is also seen as foreign and hence suspicious. Protestants face increasing persecution as a comparatively recent and rapidly growing community posing various threats to 
sociocultural order. Tibetan Buddhists are the community most severely persecuted, as they are not only seen as alien to China but also follow a leader residing abroad, the Dalai Lama. ${ }^{59}$

Where does Catholicism fit in? Without prior knowledge, one would expect Catholics to be persecuted with utmost severity. Like Tibetans, they are loyal to a religious leader and organizational platform located abroad. They have a centralized Church looking to the Pope in faraway Rome, making them more threatening than Muslims who lack a similar organization and supreme leader. All of this would point to a high level of persecution, and historically this has often been the case. At present, however, Catholics are less persecuted than Tibetans, Muslims, and Protestants.

This is due to fortuitous but contingent circumstances. Unlike the Dalai Lama, the Pope is not seen as a public enemy. The Catholic leader in recent years, Francis, is perceived as respectful of China, and Beijing considers it possible to engage in discreet negotiations with his staff. Unlike Muslims, Catholics are not associated with terrorism, separatism, and religious extremism. Catholics also appear less threatening to social order than Protestants because they are less numerous and less "urban." When compared to Protestants, some of whom are seen as given to sectarian "cults" and "western" causes such as human rights and political freedom, Catholics stand for more conservative social values that appear less dissonant with the world according to Beijing.

As much as Catholics may desire this to continue, there is no room for complacency. A lapse into more antagonistic relations has happened previously, and may happen again. In fact, there is an ongoing Sinicization campaign that may soon pose a challenge. By Sinicization, Chinese authorities hardly mean inculturation the way the Catholic Church understands the term (or, for that matter, indigenization the way Protestant churches understand it). They mean the subordination of Christianity under the supremacy of the Chinese state and Communist Party, as well as "the construction of Christianity with Chinese characteristics." ${ }^{\prime 60}$ The idea is that Christianity must reform

\footnotetext{
${ }^{59}$ See Sarah Cook, The Battle for China's Spirit: Religious Revival, Repression, and Resistance under Xi Jinping (New York: Freedom House, 2017).

${ }^{60}$ China Aid, 2014 Annual Report: Religious and Human Rights Persecution in China (Midland, TX: China Aid, 2015), 3.
} 
itself to deserve a respected position alongside other, more Sinicized religious groups-or, in other words, move closer to the civilizational core of China's informal socio-spatial hierarchy. ${ }^{61}$

The campaign was launched in 2014, initially targeting the Three-Self Protestant Movement (TSPM). In a symposium, Buddhism was praised as having successfully acquired Chinese characteristics. ${ }^{62}$ Over the next two years, the campaign gained full steam with numerous events organized to promote Sinicization. ${ }^{63}$ Thus far, Protestantism has been the principal target. However, Catholicism is far from immune. The organs of the official Church (CPCA and Bishops' Conference) have recently adopted new constitutions enshrining the concept. ${ }^{64}$ The matter has hardly been discussed in public thus far, but there is reason for concern that Sinicization may turn out to be more challenging for a Catholic Church in communion with Rome than for the Protestants gathered in the TSPM.

\section{Conclusion}

Christianity is outlandish from a Chinese and Indian civilizational perspective, and this has effects on religious freedom for Catholics and other Christians in either country. However, the effects express themselves in two different ways. In China, Christianity is foreign to a Han-centric imperial tradition of rule where the state would dominate religion and harness it for its purposes whenever the opportunity arose. In India, it is foreign to a previously subaltern society that was able to reproduce Hindu hegemony despite non-Hindu rule. In line with this difference, Christianity faces mainly social hostilities in India whereas it faces mostly government restrictions in China.

In the Chinese case, the analysis of contemporary trends might suggest that communist rule is the main challenge for the Catholic Church and other Christian denominations. If this were so, an end to

\footnotetext{
${ }^{61}$ Those favoring a Foucauldian vocabulary might say that Sinicization is a civilizational form of discipline.

${ }^{62}$ China Aid, 2014 Annual Report: Religious and Human Rights Persecution in China.

${ }^{63}$ China Aid, 2016 Annual Report: Chinese Government Persecution of Churches and Christians in Mainland China (Midland, TX: China Aid, 2017).

${ }^{64}$ UCA News, "New constitutions for Beijing-controlled church and bishops' bodies aimed at making religion in China more "Chinese"," UCA News, 21 March 2017.
} 
communist rule would end these challenges. As we have seen, however, a long and broad view suggests otherwise. Various forms of Christianity have found a marginal space in China for almost 1,400 years, but Christianity has never gained a firm and secure foothold. Government restrictions have been a persistent feature of Chinese politics, from the demise of the Nestorians to the exodus of Catholic missionaries after the rites controversy of the 17th century, from the Taiping rebellion to the Boxer uprising in the late imperial era, and from the persecution of Christian missionaries in republican times to the tribulations of the civil war, as well as the so-called Cultural Revolution. Even if we imagine an end to communist rule, the Chinese state and important sectors of Chinese society would likely remain leery of Christianity in general and Catholicism in particular.

The preferred tactic of the Catholic Church is to stress the apolitical nature of Catholicism and the possibility of dual loyalty to Rome and Beijing. While this is certainly worth the attempt, it is unlikely to fully persuade Chinese authorities. The same applies to the inclination of the Church to promote inculturation. When the Church says inculturation, it means a degree of cultural autonomy. But when Chinese authorities say Sinicization, they mean subordination to their control and insertion into a Sinocentric hierarchy. Ultimately, there is little the Church can do about the real or perceived foreignness of Christianity to China. A publication of the state-controlled Chinese official Church starts with the following sentence on the very first page: "Catholicism is foreign to China." 65

To be sure, practical accommodations are possible. Francis seems wise to focus on the appointment of bishops rather than matters of principle. However, there is a certain risk that practical accommodations and matters of principle may turn out inseparable. Focusing on the former may squander bargaining power on the latter, betraying the underground Church. The Catholic Church is a very ancient organization indeed, and it may want to take a long and principled view.

The same applies in the Indian case. A short-sighted view might suggest that Hindu nationalists are the ones mobilizing Hindu resentment against religious minorities, so their demise would end social

\footnotetext{
${ }^{65}$ Kejia Yan and Shujie Chen, Catholic Church in China (Beijing: China Intercontinental Press, 2004), 1.
} 
hostilities against Catholics and other Christians. As in the Chinese case, however, a long and broad view of civilizational legacies suggests a less optimistic picture. Christianity has been "at home" in India for almost two millennia, but its perceived foreignness remains a severe challenge.

The predominantly upper-caste Thomas Christians in the South, as well as other upper-caste Christians across the country, are firmly established and widely respected. Most Hindus see them as an asset rather than a threat. They appreciate the advanced character of these communities and their contribution to education (which they see a particular strength of Catholics). But the conversion of marginalized groups, especially Dalits and Tribals, is an entirely different matter. Outcaste proselytization is deeply resented by those who would like to keep such groups under Hindu hegemony. This is a very serious issue that sometimes leads to violence.

Education and evangelism are both close to the heart of Catholics and other Christians in India. The contribution of Christianity and especially the Catholic Church to education is most welcome as it tends to benefit the elites. The exact opposite applies to outcaste conversion, which is deeply resented. Emphasizing education and de-emphasizing evangelism may therefore mitigate social hostilities to a certain degree. On the one hand, this might sound like a betrayal of evangelism. On the other hand, however, education may also serve as a venue to pursue evangelism.

In fact, there is nothing to prevent schools from admitting talented lower- and outcaste students. Indeed, this is officially encouraged by the authorities. Education is also a good way to offer social services, from healthcare to free meals for poor students. Such services are resented when delivered in the context of outcaste conversion, but they are highly welcome in the context of education. This might suggest that, in India, the Church should focus on education, and it should do so in a way that is inclusive of Dalits and Tribals. This might then leave the door open for the Church to attract new believers (not only students but also their families) in a relatively unobtrusive way. ${ }^{66}$

\footnotetext{
${ }^{66}$ In the International Handbook of Catholic Education, an author states about India: "Catholic education needs a complete paradigm shift taking seriously the idea of education as mission. We have to work against the longestablished belief system that people in India are not meant to be equal. The Catholic identity of the school has
} 


\section{References}

Bauman, Chad M. "Hindu-Christian Conflict in India: Globalization, Conversion, and the Coterminal Castes and Tribes." Journal of Asian Studies 72, no. 3 (2013): 633-653.

Bays, Daniel H. "China." In The Wiley Blackwell Companion to World Christianity, edited by Lamin O. Sanneh, 393-402. Hoboken, NJ: Wiley Blackwell, 2016, 393-402.

--- . A New History of Christianity in China. Malden, MA: Wiley Blackwell, 2012.

Blum, Susan D. Portraits of "Primitives": Ordering Human Kinds in the Chinese Nation. Lanham: Rowman \& Littlefield, 2001.

$\mathrm{CBCl}$. Policy of Dalit Empowerment in the Catholic Church in India. New Delhi: Catholic Bishops' Conference of India, 2016.

China Aid. 2014 Annual Report: Religious and Human Rights Persecution in China. Midland, TX: China Aid, 2015.

-- - 2016 Annual Report: Chinese Government Persecution of Churches and Christians in Mainland China. Midland, TX: China Aid, 2017.

Cho, II Hyun, and Peter J. Katzenstein. "In the Service of State and Nation: Religion in East Asia." In Religion and International Relations, edited by Jack Snyder, 168-199. New York: Columbia University Press, 2011, 168-199.

Chu, Cindy Yik-yi. The Catholic Church in China: 1978 to the Present. Palgrave: Macmillan, 2013.

-- - ed. Catholicism in China, 1900-Present: The Development of the Chinese Church. New York: Palgrave Macmillan, 2014.

CNN. "As Atheist China Warms to the Vatican, Religious Persecution 'Intensifies'." CNN, 28 February 2017.

Collins, Paul M. Context, Culture and Worship: The Quest for "Indian-Ness". New Delhi: ISPCK, 2006.

Cook, Sarah. The Battle for China's Spirit: Religious Revival, Repression, and Resistance under Xi Jinping. New York: Freedom House, 2017.

Dumont, Louis. Homo Hierarchicus: The Caste System and Its Implications. Revised ed. Chicago: University of Chicago Press, 1980.

Fairbank, J.K., and S.Y. Têng. "On the Ch'ing Tributary System." Harvard Journal of Asiatic Studies 6, no. 2 (1941): 135-246.

Friedrichs, Jörg. "Sino-Muslim Relations: The Han, the Hui, and the Uyghurs." Journal of Muslim Minority Affairs 37, no. 1 (2017): 55-79.

Fuller, C.J. "Kerala Christians and the Caste System." Man 11, no. 1 (1976): 53-70.

Gaetan, Victor. "The Pope and the Politburo: The Vatican's Chinese Diplomacy." Foreign Affairs March 24 (2016).

- - - "The Vatican and China Reach a Promising Accord." Foreign Affairs March 27 (2017).

Grim, Peter. "Restrictions on Religion in the World." In The Future of Religious Freedom, edited by Allen D. Hertzke, 86-104. New York: Oxford University Press, 2013, 86-104.

Haas, Benjamin, and Tom Phillips. "Pope's Possible Deal with China Would 'Betray Christ', Says Hong Kong Cardinal." The Guardian, 28 November 2016.

Hacker, Paul. "Inklusivismus." In Inklusivismus: Eine Indische Denkform, edited by Gerhard Oberhammer, 11-28. Wien: Institut für Indologie der Universität Wien, 1983, 11-28.

Halbfass, Wilhelm. India and Europe: An Essay in Understanding. New York: SUNY Press, 1988.

Harrell, Stevan, ed. Cultural Encounters on China's Ethnic Frontiers. Seattle: University of Washington Press, 1995.

to be maintained by admitting Catholic children, as well as other children. (...) A new Vatican II-inspired Catholic educational mission is in the process of developing in India." Nicholas Tete, "Catholic education in India: Challenge, Response, and Research," in International Handbook of Catholic Education: Challenges for School Systems in the 21st Century, ed. Gerald Grace and Joseph O'Keefe (Dordrecht: Springer, 2007), 683-694, 693. 
Johnson, Ian. The Souls of China: The Return of Religion after Mao. London: Allen Lane, 2017. Katju, Manjari. "The Politics of Ghar Wapsi." Economic \& Political Weekly 50, no. 1 (2015): 21-24.

Kwong, Luke S.K. "What's in a Name: Zhongguo (or 'Middle Kingdom') Reconsidered." Historical Journal 58, no. 3 (2015): 781-804.

Legge, James. The Chinese Classics. Vol. 3. Hongkong and London: Trübner \& Co., 1865.

Leung, Beatrice. Sino-Vatican Relations: Problems in Conflicting Authority, 1976-1986. Cambridge: Cambridge University Press, 1992.

Leung, Beatrice, and Marcus J.J. Wang. "Sino-Vatican Negotiations: Problems in Sovereign Right and National Security." Journal of Contemporary China 25, no. 99 (2016): 467-482.

MacCulloch, Diarmaid. A History of Christianity: The First Three Thousand Years. London: Penguin, 2010.

Mahmood, Cynthia Keppley. "Rethinking Indian Communalism: Culture and Counter-Culture." Asian Survey 33, no. 7 (1993): 722-737.

Mariani, Paul P. "The Four Catholic Bishops of Shanghai: "Underground" and "Patriotic" Church Competition and Sino-Vatican Relations in Reform-Era China." Journal of Church and State 58, no. 1 (2016): 38-56.

McCarthy, Susan K. Communist Multiculturalism: Ethnic Revival in Southwest China. Seattle: University of Washington Press, 2009.

Milner, Murray. Status and Sacredness: A General Theory of Status Relations and an Analysis of Indian Culture. New York: Oxford University Press, 1994.

Moody, Peter R. "The Catholic Church in China Today: The Limitations of Autonomy and Enculturation." Journal of Church and State 55, no. 3 (2013): 403-431.

Nehru, Jawaharlal. The Discovery of India. London: Meridian, 1946.

Pallath, Paul. The Catholic Church in India. Rome: Mar Thoma Yogam, 2003.

Panganiban, Patricia G. "Inculturation and the Second Vatican Council." Landas 18, no. 1 (2004): 5993.

Pew Research Center. The Future of World Religions: Population Growth Projections, 2010-2050. Washington, DC: Pew Research Centre, 2015.

-- - Global Christianity: A Report on the Size and Distribution of the World's Christian Population. Washington, DC: Pew Research Forum, 2011.

Smith, Richard J. Chinese Maps: Images of "All under Heaven". Hong Kong: Oxford University Press, 1996.

Srinivas, M.N. "A Note on Sanskritization and Westernization." Far Eastern Quarterly 15, no. 4 (1956): 481-496.

Tete, Nicholas. "Catholic Education in India: Challenge, Response, and Research." In International Handbook of Catholic Education: Challenges for School Systems in the 21st Century, edited by Gerald Grace and Joseph O'Keefe, 683-694. Dordrecht: Springer, 2007, 683-694.

UCA News. "New Constitutions for Beijing-Controlled Church and Bishops' Bodies Aimed at Making Religion in China More "Chinese"." UCA News, 21 March 2017.

Wenzel-Teuber, Katharina. "Statistics on Religions and Churches in the People's Republic of China: Update for the Year 2016." Religions and Christianity in Today's China 7, no. 2 (2017): 26-53.

Wiest, Jean-Paul. "Sino-Vatican Relations under Pope Benedict Xvi: From Promising Beginnings to Overt Confrontation." In Catholicism in China, 1900-Present: The Development of the Chinese Church, edited by Cindy Yik-Yi Chu, 189-216. New York: Palgrave Macmillan, 2014, 189-216.

Yan, Kejia, and Shujie Chen. Catholic Church in China. Beijing: China Intercontinental Press, 2004.

Yang, Yi. "Between God and Caesar: The Catholic Bishops' Election and Consecration in China." Journal of Contemporary China, no. forthcoming (2017).

Zhang, Yongjin, and Barry Buzan. "The Tributary System as International Society in Theory and Practice." Chinese Journal of International Politics 5, no. 1 (2012): 3-36.

Zhu, Rachel Xiaohong. "The Division of the Roman Catholic Church in Mainland China: History and Challenges." Religions 8, no. 3 (2017): 14 pp. 